\title{
The Hidden Voyage of a Dying Italian Company, from the Mediterranean Sea to Albion
}

\author{
- A Comment to the ECJ Decision "Interedil” on Cross-Border \\ Transfer of Registered Office before the Filing for Insolvency -
}

by

\author{
Federico M. Mucciarelli ${ }^{1}$
}

For the first time, the European Court of Justice addresses a case of a cross-border transfer of registered office before the filing for insolvency. The Interedil decision makes clear that the location of a debtor's centre of main interests ("COMI") is to be assessed as of the moment of filing for insolvency. Furthermore, the ECJ addresses the question of the evidence required to overcome the presumption that the COMI coincides with a corporation's registered office. However, behind these relevant cross-border insolvency issues hides a strange story of corporate mobility from Italy to England, which shows the need for further harmonization throughout the EU in the field of cross-border transfer of register offices.

\section{Table of Contents $\quad$ ECFR 2012, 571-579}

I. Preamble: the Insolvency Regulation on Cross-Border Insolvencies . . . . 571

II. The Voyage of Interedil . . . . . . . . . . . . . . . . . . . . . . . . 573

III. Fuzziness of Italian Law on Cross-Border Transfer of Statutory Seats . . . 575

IV. The ECJ Decision on the Location of the COMI . . . . . . . . . . . . . 576

V. The ECJ Decision on the Transfer of the Registered Office Before the Filing

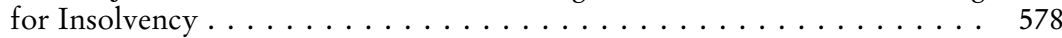

\section{Preamble: the Insolvency Regulation on Cross-Border Insolvencies}

Once again, the European Court of Justice ("ECJ”) issues a preliminary ruling on the interpretation of the European Insolvency Regulation², although for the first time the case referred to the court is one of corporate mobility prior to an insolvency filing.

1 University of Modena and Reggio Emilia, Department of Economics - University of London, Soas.

2 Regulation 1346/2000. 
According to the European Insolvency Regulation, insolvency main proceedings $^{3}$ are regulated by the court and by the law of the member state in which the debtor's centre of main interests (COMI) sits. To simplify the process of determining a COMI's location, the European Insolvency Regulation presumes that, if the insolvent debtor is a corporation, its COMI coincides with the registered office, unless the contrary is proven ${ }^{4}$. Consequently, if the debtor or its creditors do not prove the contrary, the member state that regulates a corporation's life is also competent to govern its bankruptcy. The goal of these provisions is to avoid forum shopping ${ }^{5}$, as the drafters held that corporate headquarters and registered offices could not be easily transferred from one state to another.

This premise, however, is far from being realistic anymore. Indeed, in recent years ECJ's case law has partially liberalized corporate mobility and incorporations ${ }^{6}$; nowadays, newly established companies can be incorporated in one member state and yet have their business and headquarters in other member states (providing that the state of incorporation accepts this dissociation).

Furthermore, corporations can transfer their COMI from one state to another by transferring the registered office, thereby shifting the presumption embodied in the Insolvency Regulation. Indeed, since a directive on cross-border mergers was enacted in $2005^{7}$, corporations can now reincorporate from one member state to another by merging the existing corporation into a newlycreated shell company incorporated in the other member state. This mechanism, however, is costly and time consuming and corporate mobility would be better served if corporations could directly transfer their registered office from one state to another. Some member states, however, still do not allow reincorporations by way of transfer of registered office. In this regard, the ECJ has stated that freedom of establishment protects the right to reincorporate from one state to another ${ }^{8}$, yet this statement was probably a not binding

3 Besides this main proceeding with universal effects, however, courts of states of a debtor's "establishments" can open ancillary proceeding with mere territorial effects and aimed at liquidation: article 3 \$2 Insolvency Regulation

4 Article $3 \$ 1$ Insolvency Regulation.

5 Recital 4 Insolvency Regulation.

6 ECJ C-212/97, Centros Ltd v Erhvervsog Selskabsstyrelsen [1999] ECR I-1459; ECJ C208/00, Überseering BV v Nordic Construction Company Baumanagement GmbH [2002] ECR I-9919; ECJ C-167/01, Kamer van Koophandel en Fabrieken voor Amsterdam v. Inspire Art, [2003] ECR I-1095.

7 Directive 2005/56/CE, of the Parliament and the Council, October $26^{\text {th }} 2005$, on crossborder mergers of limited liability companies.

8 ECJ, C-210/06, CARTESIO Oktató és Szolgáltató [2008] ECR I-09641. See: Stefano Lombardo, "Regulatory Competition in Company Law in the European Union after Cartesio”, 10 European Business Organization Law Review, 627, (2009). 
obiter dictum. Recently, the ECJ has considered the limits inbound states have placed on cross-border reincorporation, holding that the refusal to register the incoming corporation is a violation of freedom of establishment ${ }^{9}$. In 2007, a XIV directive on company law regulating cross-border transfers of registered office was eventually abandoned; however, this issue remains on the political agenda of both the European Commission and the European Parliament ${ }^{10}$. For the time being, member states behave independently from one another with regard to cross-border conversion of domestic companies; while some allow reincorporation abroad and govern this transaction to protect minority shareholders and creditors, other states do not accept this transaction at all ${ }^{11}$. In this respect, Italian law is extremely fuzzy and uncertain: cross-border transfers of statutory seat are explicitly allowed by the Italian Civil Code, yet their effect on the applicable company law is uncertain and, most importantly, the whole proceeding is unregulated.

\section{The Voyage of Interedil}

Interedil was an Italian limited liability corporation (società a responsabilità limitata) with statutory seat in Monopoli and was registered in the commercial register' office of Bari since 1996 ${ }^{12}$. On July $18^{\text {th }} 2001$ the general meeting of Interedil decided to transfer its statutory seat from Monopoli to London. On October 23 2001, Interedil was registered in the English Company House as an "overseas company", having - according to the Company House - transferred a "place of business" to England.

Therefore, for the English Company House, Interedil was still an Italian company, which simply established a place of business in England. To the contrary, under the viewpoint of Italian law and of the Italian register, Interedil had transferred to England its statutory seat.

Indeed, on the same date (July 18 th 2001) Interedil filed with the register of Bari a cancellation request and then, on September $5^{\text {th }} 2001$, the Interedil was

9 ECJ, C-378/10, VALE Építési kft [2012]: conversion of an Italian corporation into an Hungarian one.

10 European Parliament resolution of 2 February 2012 with recommendations to the Commission on a $14^{\text {th }}$ company law directive on the cross-border transfer of company seats, and Reflection Group on the future of EU company law, 5 April 2011, 17 - 20.

11 On reincorporations, see: Federico M. Mucciarelli, “The Function of Corporate Law and the Effects of Reincorporations in the U.S. and the EU”, 20 Tulane Journal of International and Comparative law, 421 (2012).

12 I got information on the facts of the Interedil case by consulting directly the English company house (http://www.companieshouse.gov.uk/) and the Italian corporate register (http://www.registroimprese.it) data bases. 
eventually cancelled from the Italian register. We should pay attention to the dates: Interedil was registered in England only on October 23, a month and a half after the cancellation from the Italian register: during this month and a half, Interedil was a sort of ghost company, since it was neither registered in Italy nor in England. After October 23, however, Interedil continued to be a strange creature, because it was registered in England as a branch of an Italian company, despite it was not registered in Italy anymore.

Curiously enough, on July $22^{\text {nd }} 2002$ Interedil was eventually cancelled from the English register also, having ceased to hold a "place of business" in England. Obviously, this cancellation did not require a liquidation proceeding, because from the viewpoint of the English authorities Interedil was simply an Italian company moving its place of business out of England. After July 22nd 2002, therefore, Interedil simply disappeared from both registers, although it did not go through a liquidation proceeding either in England or in Italy.

On October 23 2003, an important creditor (Intesa Gestione Crediti) filed for insolvency at the Tribunal of Bari (where Interedil was originally registered). Interedil opposed that the registered office was transferred to England and, therefore, that only English courts were competent to open an insolvency proceeding according to the European Insolvency Regulation. As we have seen above, however, things were more complicated and confused: first of all, at the moment of filing, Interedil was registered neither in England nor in Italy and, secondly, from the viewpoint of Italian law Interedil had actually transferred its statutory seat to England, while for English law it was an Italian company. Nonetheless, the Tribunal of Bari recognized that Interedil's COMI was in Italy and opened an insolvency proceeding; Interedil asked to the Corte di Cassazione a preliminary judgement on the attribution of competence. The Corte di Cassazione held the presumption of coincidence between COMI and registered office as rebutted because Interedil owned real estates, leased an Hotel and had a bank account in Italy. Despite the decision of the Cassazione, the Tribunal of Bari, was not convinced and submitted to the ECJ following preliminary questions:

1. Is the term "the centre of a debtor's main interests" [...] to be interpreted in accordance with Community law or national law, and, if the former, how is that term to be defined and what are the decisive factors or considerations for the purpose of identifying the "centre of main interests"?

2. Can the presumption laid down in Article 3(1) of [the] Regulation [..., be rebutted if it is established that the company carries on genuine business activity in a State other than that in which it has its registered office, or is it necessary, in order for the presumption to be deemed rebutted, to establish that the company has not carried on any business activity in the State in which it has its registered office? 
3. If a company has, in a Member State other than that in which it has its registered office, immovable property, a lease agreement concluded by the debtor company with another company in respect of two hotel complexes, and a contract with a banking institution, are these sufficient factors or considerations to rebut the presumption $[\ldots]$ ?

\section{Fuzziness of Italian Law on Cross-Border Transfer of Statutory Seats}

This short account of the facts behind the Interedil case shows clearly what the problem is: Italian rules related to cross-border transfer of statutory seats are fuzzy and incomplete, so that shareholders and directors can behave opportunistically at creditors' expenses.

According to the Italian Civil Code, a corporations' general meeting can decide to transfer abroad its statutory seat and, following this decision, dissenting shareholders enjoy a withdrawal right. A withdrawal right is a typical legal mechanism to protect minority shareholders against the risk of opportunistic decisions of the majority, such as cross-border conversions ${ }^{13}$. The Italian Civil Code, however, does not provide for any mechanism for creditors' protection in case of cross border transfer of statutory seat; additionally, commercial register' offices and notaries do not apply analogically the rules on mergers or conversions aimed at protecting pre-existing creditors, which raises the risk of opportunistic forum shopping, as is shown by the Interedil case $^{14}$. Furthermore, there is no explicit provision governing the proceeding and the technicalities of such transfer.

From a private international law viewpoint it is not even clear whether a transfer of statutory seat changes the applicable company law, and, therefore, whether this decision leads, or can lead, to cancel the company from the Italian register. In this regard, case law predominantly, albeit not unanimously, holds that cross-border reincorporations are not allowed even after a decision to transfer the statutory seat abroad. Nonetheless, the local offices of the commercial register ignore such mainstream case law and implement cross-border conversions. On top of that, such local offices are not coordinated and behave inconsistently as regards the proceeding to cancel the "emigrating" company:

13 See: Ventoruzzo, "Cross-border Mergers, Change of Applicable Corporate Laws and Protection of Dissenting Shareholders: Withdrawal Rights under Italian Law”, European Company Financial Law Review, 2007, 47 et seq.

14 As suggested by Benedettelli, "Libertà comunitarie di circolazione e diritto internazionale private", Rivista italiana di diritto internazionale privato e processuale, 568, 615 (2001) and Mucciarelli, Società di capitali, trasferimento all'estero della sede sociale e arbitraggi normativi, 193 - 194 (2010). 
some of them - such as the register of Bari in the Interedil case - cancel the company without waiting its registration in the new country, while other offices - such as, for instance, the register of Milan - cancel emigrating companies only after their registration in the new register ${ }^{15}$. In this respect, it is worth mentioning the position of the Italian government in the recent "Vale" case, mentioned above, where an Italian company decided to transfer its statutory seat to Hungary and to convert in a Hungarian company ${ }^{16}$. The Italian government, required to explain how Italian law regulates cross-border transfers of statutory seats, stated that emigrating companies can be cancelled only after being registered in the new register ${ }^{17}$. However, a number of local offices of the Italian commercial register simply ignore such interpretation.

It is worth mentioning also that the recent Directive on the interconnection of commercial and companies' registers ${ }^{18}$ requires member registers' to "make available, without delay, the information on the opening and termination of any winding-up or insolvency proceedings of the company and on the striking-off of the company from the register" ${ }^{19}$, through the centralized electronic platform that will be implemented by the Commission. Maybe, after the implementa, of the directive a new "Interedil case" will become less limetly.

\section{The ECJ Decision on the Location of the COMI}

Let's turn our attention now to the ECJ's decision. After having confirmed that the concept of COMI of the Insolvency Regulation should be interpreted exclusively according to European Union law ${ }^{20}$, the ECJ addressed the questions of the elements that should be proved in order to rebut the presumption that the COMI coincides with the registered office. In this regard, the ECJ stated that the presence of

15 For an account of Italian case law and commercial register decisions, see: Mucciarelli, Società di capitali, trasferimento all'estero della sede sociale e arbitraggi normativi, 167 181 (2010).

16 See footnote 10.

17 See: Opinion of the General Advocat Niilo Jääskinen, December 15th 2011, paragraph 40.

18 Directive 2012/17/EU of the European Parliament and the Council of 13 June 2012, amending Council Directive 89/666/EEC and Directives 2005/56/EC and 2009/101/ EC of the European Parliament and of the Council as regards the interconnection of central, commercial and companies registers.

19 Directive 2009/101/EC, art. 3 d.

20 ECJ Interedil, para 42; on the interpretation of EU law concepts, see: Lutter, "Die Auslegung angeglichenen Rechts”, Juristenzeitschrift, 593 et seq. (1992). 
immovable property owned by the debtor company, in respect of which the company has concluded lease agreements, and the existence in that Member State of a contract concluded with a financial institution [...] may be regarded as objective factors and, in the light of the fact that they are likely to be matters in the public domain, as factors that are ascertainable by third parties ${ }^{21}$.

These elements, however, in ECJ's mind, are not sufficient to rebut the presumption

unless a comprehensive assessment of all the relevant factors makes it possible to establish, in a manner that is ascertainable by third parties, that the company's actual centre of management and supervision and of the management of its interests is located in that other Member State.

We can say that the Interedil decision has developed the Eurofood dictum, according to which, in order to rebut the presumption that the COMI coincides with the registered office, evidence must be provided that its different location is recognizable by third parties ${ }^{22}$. In the Court's view, elements such as real estate or financial contracts can be used to convince the court of the real COMI location, yet they are not per se sufficient and can only be part of a global consideration of what is recognized by creditors as the centre of corporate business.

The Insolvency Regulation relies upon the factual criterion of COMI also with the aim that the member state closest to the involved stakeholders (such as creditors or employees) govern a debtor's default ${ }^{23}$. If the COMI was simply in the state of a corporate headquarter, however recognizable it may be, dissociations between COMI and business' activities would be possible and the function of the COMI criterion would be jeopardized. In the Interedil decision, the ECJ puts in clear words that elements different from corporate' headquarter, such as immovable property, lease agreements or bank and financial contracts, can legitimately convince a court that a debtor's COMI was in a member state different from the state of the registered office ${ }^{24}$. In this regard,

21 ECJ Interedil, para 53.

22 ECJ, C-341/04, Eurofood IFSC Ltd, [2006] ECR-I 1078.

23 Benedettelli, "Centro degli interessi principali del debitore e forum shopping nella disciplina comunitaria delle procedure di insolvenza transfrontaliera", Rivista italiana di diritto internazionale privato e processuale, 499, 516 - 517 (2004).

24 This line of thought is not new, however, as two recent examples show: (a) In the Brochier case, a German company converted into an English one, without moving any assets and activities from Germany to England, and the English judges denied to be competent to open the insolvency (High Court Chancery Division, Hans Brochier Holding Ltd v. Exner, "Brochier”, [2006] EWHC 2594 see: Wolf-Georg Ringe, "Forum shopping under the EU insolvency regulation”, European Business Organization Law Review, 579, 585 - 586 (2009) and Marc-Philippe Weller, "Die Verlegung des Centre of Main Interest von Deutschland nach England”, Zeitschrift für das gesamte Handelsund Gesellschaftsrecht, 835, 863 (2008); (b) In the IT case, a Luxemburg sub-holding was declared insolvent in Italy, because it did not have any activity in the state of the registered office (Tribunale Isernia, 10. 4. 2009, Il Fallimento, 2010, 59) 
the Interedil decision develops end expands the Eurofood opinion, where the ECJ claimed

that the mere fact that its economic choices are or can be controlled by a parent company in another Member State is not enough to rebut the presumption laid down by the Regulation ${ }^{25}$.

\section{The ECJ Decision on the Transfer of the Registered Office Before the Filing for Insolvency}

The real peculiarity of the Interedil case is that the debtor transferred its statutory seat from one state to another before the filing for insolvency. Before the Interedil decision, the ECJ had only addressed the transfer of head office of an individual firm after the filing for insolvency and before the decision to open an insolvency proceeding, stating that such a transfer is not relevant to shift the international competence from the first member state to the second one ${ }^{26}$. The ECJ, however, had not yet addressed transfers of headquarter or registered office before the filing for insolvency. Obviously, the main risk of such transfers is that shareholders and directors can act opportunistically at the expenses of pre-existing local creditors. It was, therefore, debated whether member states could consider such transfers before the filing for insolvency as "abusive" 27.

The Interedil decision clearly answered this question, by stating that the COMI must be assessed as to the date of the filing of insolvency, even if the registered office is transferred before the filing. Consequently, by transferring the registered office from one member state to another before the filing, a debtor transfers also the presumption that the COMI coincides with the registered office.

Such presumption can be overcome, if creditors of the original member state convince a court that debtors' activities are still in the original country. Furthermore, the principle of priority, according to which the first member state that opens a proceeding prevail ${ }^{28}$, risks to preclude any further inquiry as to the real place of the COMI. In practice, only sophisticated creditors will have the interest - and the money - to try to overcome the presumption that the COMI coincides with the registered office, while local non-adjusting creditors will probably not. This means that, although on the book the COMI criterion,

25 Eurofood, para 36.

26 ECJ, C-1/04 Staubitz-Schreiber [2006] ECR-I 00701.

27 See: Eidenmüller, "Abuse of law in European insolvency law”, European Company Financial Law Review, 15 (2009), arguing that abuse of law presumptions are not compatible with the Insolvency regulation.

28 Recital 22 Insolvency Regulation. 
based upon empirical elements, is meant to protect creditors from opportunistic forum shopping, in the real world things can be much more complicated and a transfer of registered office is likely to jeopardize weak creditors.

The Interedil case and these risks of opportunistic regulatory arbitrages show that there is a need for an intervention of the E.U. to harmonize the rules on creditors' protection in case of cross-border transfers of registered office. 